\title{
Promising varieties of fiber and oil flax plants for agricultural technologies of Trans-Urals
}

\author{
Igor Porsev*, Andrey Sozinov, Georgy Karpov, and Ksenia Salomatina \\ Kurgan State Agricultural Academy named after T. S. Maltsev, 641300 Kurgan region, Russia
}

\begin{abstract}
Cultivation of fiber flax and oil flax in Kurgan region is of current interest due to the presence of flax seed and straw processing enterprise - SUE Len Zauralya, Kurgan. To increase the production of highquality flaxseed oil and flax products, the level of flax production should be increased via theoretically substantiated cultivation technologies. Propagating a new variety, plant breeders consider the needs of two categories of consumers - flax producers and flax processors. Some of them need fiber flax varieties of high yield (seed and fiber) and high fiber quality resistant to diseases and lodging, adapted to conditions of Trans-Urals and Siberia. Other consumers need fiber flax varieties that meet numerous requirements of textile, construction, automotive, aviation, medical, and other sectors of the economy, and are suitable for processing by state-of-the-art flax processing equipment. The approach to develop a variety has currently become targeted and customized. Varieties grown in the study area and used as a standard showed high fiber yields: Tomsky $17-0.68 \mathrm{t} / \mathrm{ha}$, Tomsky $18-0.69 \mathrm{t} / \mathrm{ha}$. The results of the three-year study showed high yields of new varieties: Tost $3-0.98 \mathrm{t} / \mathrm{ha}$, Tost $4-0.86 \mathrm{t} / \mathrm{ha}$, Tost $5-0.82 \mathrm{t} / \mathrm{ha}$. The fiber yield of these varieties was also high: Tost $3-0.71 \mathrm{t} / \mathrm{ha}$, Tost $4-0.68 \mathrm{t} / \mathrm{ha}$, Tost $5-0.66 \mathrm{t} / \mathrm{ha}$.
\end{abstract}

\section{Introduction}

The main goal of fiber flax culture is to obtain fibers formed in its stems. Fibers contain $20-30 \%$ of fibrous substances. The technical stem, the part from the hypocotyl to the point where inflorescence starts, which yields long fiber, is of production interest [1-4].

Severny hybrid variety and Itil, Lirin and VNIIMK 620 oil flax varieties are mainly sown to yield seeds for oil production in Kurgan region [5, 6].

The studies were conducted in 2017-2019 at the Department of Land Management, Agriculture, Agrochemistry and Soil Science and the experimental plot of Kurgan State Agricultural Academy. Field experiments were performed in accordance with the Guidelines for conducting field experiments with fiber flax [1969; 1978]; Methods of state variety testing [1985]. The variants in the experimental plot of Kurgan State Agricultural Academy are placed randomly with 6fold repetition. The experimental seed application rate was $18 \mathrm{mln}$ of fiber flax germinating seeds/ha and $8 \mathrm{mln}$ of oil flax germinating seeds/ha [4-6].

The study objects were 10 fiber flax varieties and 8 oil flax varieties.

Weather conditions during the experiments with fiber flax varieties were favorable and varied from 1.0 hydrothermal coefficient in 2018 to 1.2 hydrothermal coefficient in 2017. The weather during the vegetation period of 2019 was cold in June and hot in July and August. Precipitations attained $83 \%$ of the norm in June, and $67 \%$ of the norm in July. Dry winds from July 13 to July 17 contributed to partial death of flax inflorescences. Precipitations in August amounted to $186 \%$ of the norm, which extended flax vegetation period.

\section{Materials and Methods}

Flax varieties were grown with regard to fallow and spring wheat, and the experiment with leguminous herbicides was performed using the recommended zone technology [7]. Root rot was recorded in accordance with V.A. Chulkina. Mycological analysis and phytopathogen identification was performed in complience with the method by V.I. Bilai, N.M. Pidoplichko. The number of plant seeds in the soil was recorded by A.G. Taskaeva's technique. Clogged crops were estimated by quantitatively-weighing method [8].

Phyto-examination of flax seeds for sowing in conditions of the South Trans-Urals was performed annually. Sowing qualities of seeds obtained in the experiment were as follows: purity (GOST 12037-81); germination energy and germinating ability (GOST 12038-84); weight of 1000 seeds (GOST 12042-80); infection of seeds with seed wilts (GOST 12044-93); mass fraction of seedfat (GOST 13496.13-97).

The soil section was used to describe the soil in the experimental plot. Agrochemical properties of the soil were analyzed by generally accepted methods: exchange

\footnotetext{
Corresponding author: porsev_in66@mail.ru
} 
potassium and mobile phosphorus by A.T. Kirsanov's method modified by CINAO GOST 26207-91 modification, humus by I.V. Tyurin's method modified by CINAO GOST 26213-91, exchange acidity $(\mathrm{pH}$ in salt extract) was analyzed by the potentiometric method modified by CINAO GOST 26483-85. Soil moisture was estimated by gravimetric method.

Determination of standard quantity of seed per hectare, phenological observations, and morphological analysis of the plants were carried out using Guidelines for conducting field experiments with fiber flax [9].

Doses of mineral fertilizers were calculated by the balance method for the expected seed yield of $10 \mathrm{c} / \mathrm{ha}$. A continuous seed yield in each plot was recorded with conversion to standard humidity of $12 \%$ (GOST 1203781 ) and $100 \%$ purity (GOST 12041-82). Biological seed and straw yields were determined from experimental plots [9].

Variance analysis and correlation-regression data mining were performed by the method proposed by B.A. Dospekhov.

Energy and economic assessment of the technological methods was carried out using technological maps of fiber flax and oil flax cultivation.

The key indicators used to assess flax varieties are as follows:

a) yield of flax straw, seeds, long and entire fiber;

b) yield of the entire fiber (in \%);

c) duration of the growing season;

d) plant height;

e) resistance to diseases and pests;

Testing of varieties is carried out in the corresponding field of crop rotation of the variation plot with respect to the best predecessors adopted for flax in production in the specific zone.

\section{Results and Discussion}

The results of the three-year study showed a high seed yield of fiber flax of Tomsk selection in control groups (Table 1).

Reproduction conditions affected the yield of flax varieties. The table shows that the lowest seed yield on average for the varieties was obtained in 2019.

Table 1. Seed yields of fiber flax varieties (experimental plot, Kurgan State Agricultural Academy)

\begin{tabular}{|l|c|c|c|c|}
\hline \multirow{2}{*}{\multicolumn{1}{|c|}{ Variety }} & \multicolumn{4}{c|}{ Yield, t/ha } \\
\cline { 2 - 5 } & 2017 & 2018 & 2019 & average \\
\hline Tomsky 17 (standard) & 0.90 & 0.85 & 0,87 & 0.87 \\
\hline Tomsky 18 & 0.84 & 1.02 & 0.82 & 0.89 \\
\hline Tost & 0.75 & 0.87 & 0.76 & 0.79 \\
\hline Tost 3 & 1.01 & 1.05 & 0.88 & 0.98 \\
\hline Tost 4 & 0.95 & 0.88 & 0.76 & 0.86 \\
\hline Tomich & 0.72 & 0.72 & 0.70 & 0.71 \\
\hline Pamyati Krepkova & 0.78 & 0.75 & 0.72 & 0.75 \\
\hline Soyuz & 0.76 & 0.79 & 0.78 & 0.78 \\
\hline Smolensky & 0.83 & 0.72 & 0.81 & 0.79 \\
\hline Tost 5 & - & 0.82 & 0.81 & 0.82 \\
\hline Average by varieties & 0.84 & 0.85 & 0.79 & 0.82 \\
\hline
\end{tabular}

\begin{tabular}{|l|l|l|l|l|}
\hline LSD $_{0.95}$ & 0.08 & 0.06 & 0.03 & \\
\hline
\end{tabular}

Not only high agricultural background and favorable environmental conditions but also high-yielding varieties, protection of crops from pests, diseases, and weeds are required to ensure seed and highquality flax straw yields.

To have high yields of high-quality fiber, the length of the technical stems should be not less than $65 \mathrm{~cm}$ with a minimum size of inflorescences and with their average diameter at half height of no more than 1.5 $\mathrm{cm}$.

It is also important to have stems closer to the cylinder in shape to have the smallest decrease (the ratio of the diameters of the lower and upper stem parts), which approaches unity.

The new varieties that showed a high yield of fiber were Tost $3-0.71 \mathrm{t} / \mathrm{ha}$, Tost $4-0.68 \mathrm{t} / \mathrm{ha}$, Tost $5-0.66 \mathrm{t} / \mathrm{ha}$ (Table 2 ).

Table 2. Seed yields of fiber flax varieties over the study years (experimental plot, Kurgan State Agricultural Academy)

\begin{tabular}{|l|c|c|c|c|}
\hline \multirow{2}{*}{\multicolumn{1}{|c|}{ Variety }} & \multicolumn{4}{c|}{ Yield, t/ha } \\
\cline { 2 - 5 } Tomsky 17 (standard) & 2017 & 2018 & 2019 & average \\
\hline Tomsky 18 & 0.81 & 0.55 & 0.67 & 0.68 \\
\hline Tost & 0.74 & 0.64 & 0.68 & 0.69 \\
\hline Tost 3 & 0.73 & 0.54 & 0.64 & 0.64 \\
\hline Tost 4 & 0.83 & 0.57 & 0.74 & 0.71 \\
\hline Tomich & 0.79 & 0.55 & 0.70 & 0.68 \\
\hline Pamyati Krepkova & 0.66 & 0.52 & 0.64 & 0.61 \\
\hline Soyuz & 0.68 & 0.53 & 0.60 & 0.60 \\
\hline Smolensky & 0.74 & 0.60 & 0.64 & 0.66 \\
\hline Tost 5 & 0.80 & 0.62 & 0.68 & 0.70 \\
\hline Average by varieties & - & 0.58 & 0.73 & 0.66 \\
\hline LSD $_{0.95}$ & 0.75 & 0.57 & 0.67 & 0.66 \\
\hline
\end{tabular}

Seed yields of oil flax new varieties over the study years was found to be high (Table 3 ).

The three-year study showed the best results of seed yields among the new white-grain varieties for flax varieties LM $98-2.44 \mathrm{t} / \mathrm{ha}$ and Itil $-2.28 \mathrm{t} / \mathrm{ha}$, the yield of Raciol variety was found to decrease. The new variety Uralsky Zhelty in 2019 exhibited a good seed yield. Oily raw materials produced from flax seeds of yellowgrained varieties LM 98, Itil and Uralsky Zhelty are a source of weakly pigmented vegetable oil and highquality feed concentrate. The seed coat of the seeds of yellow seed flax varieties are thinner. As a result, oil and protein content increases, which provides a greater oil yield during processing and high energy value of meal. 
Table 3. Seed yields of oil flax varieties over the study years (experimental plot, Kurgan State Agricultural Academy)

\begin{tabular}{|l|c|c|c|c|}
\hline \multirow{2}{*}{\multicolumn{1}{c|}{ Variety }} & \multicolumn{4}{c|}{ Yield, t/ha } \\
\cline { 2 - 5 } & 2017 & 2018 & 2019 & average \\
\hline Severny (standard) & 2.70 & 2.26 & 3.79 & 2.92 \\
\hline Itil & 2.34 & 1.98 & 2.51 & 2.28 \\
\hline VNIIMK-620 & 2.29 & 1.87 & 2.04 & 2.07 \\
\hline LM-98 & 2.55 & 2.06 & 2.70 & 2.44 \\
\hline Lirina & - & 2.19 & 2.75 & 2.47 \\
\hline Uralsky & - & - & 3.91 & 3.91 \\
\hline Uralsky Zhelty & - & - & 2.78 & 2.78 \\
\hline Raciol & - & - & 1.91 & 1.91 \\
\hline LSD 0.95 & 0.08 & 0.06 & 1.30 & \\
\hline
\end{tabular}

The value of flaxseed depends primarily on the oil content and its fatty acid composition, and protein content. The seeds of various flax varieties differ in the content of these basic nutrients (Table 4).

Linseed cake is of high energy value: $1 \mathrm{~kg}$ of linseed cake contains 1.27 f.u., $13.73 \mathrm{MJ}$ and $287 \mathrm{~g}$ of digestible protein; composition rich in micronutrients and vitamins.
Linseed cake protein is highly digestible with a good amino acid composition. Fats that remain in linseed cake after oil distillation exhibit all the beneficial properties of linseed oil.

Among fiber flax varieties, the highest oilseed content was observed in Tost $3-43.41 \%$, Tost 4 $43.27 \%$ and Pamyati Krepkova - $43.24 \%$, and the highest crude protein content was found in Tost $30.28 \%$ and Tost $3-28.46 \%$. Flaxseed oil is unique in its high content of alpha-linolenic (omega-3) fatty acid and other unsaturated fatty acids. Flaxseed oil twice exceeds fish oil in the content of unsaturated fatty acids,.

Flax varieties are grown to produce long fiber, and seeds can be used to produce oil. The seed yield of oil flax varieties is higher than that of fiber flax due to the fact that they belong to different varieties. Among the oil flax varieties, the highest oil content of $46.13 \%$ and oil collection of $1347 \mathrm{~kg} / \mathrm{ha}$ was observed in Severny variety with a seed yield of $2.92 \mathrm{t} / \mathrm{h}$. Oil yield from yellow-grain varieties LM 98 and Itil amounted to $1050.4 \mathrm{~kg} / \mathrm{ha}$ and $957.8 \mathrm{~kg} / \mathrm{ha}$, respectively.

Table 4. Content and yield of oil and protein in different varieties of fiber and oil flax plants

\begin{tabular}{|c|c|c|c|c|}
\hline \multirow{2}{*}{ Variety } & \multicolumn{2}{|c|}{ Oil content } & \multicolumn{2}{c|}{ Crude protein } \\
\cline { 2 - 5 } & content, \% & yield, kg/ha & content, \% & yield, kg/ha \\
\hline \multicolumn{5}{|c|}{ Fiber flax } \\
\hline Tomsky-18 & 42.56 & 370.3 & 27.68 & 240.8 \\
\hline Tomsky-17 & 42.42 & 377.5 & 26.44 & 235.3 \\
\hline Tost & 38.06 & 300.7 & 30.28 & 239.2 \\
\hline Tost-3 & 43.41 & 425.4 & 28.46 & 278.9 \\
\hline Tost-4 & 43.27 & 372.1 & 27.52 & 236.7 \\
\hline Tomich & 42.85 & 304.2 & 25.98 & 184.5 \\
\hline Pamyati Krepkova & 43.24 & 324.3 & 28.37 & 201.4 \\
\hline Smolensky & 39.41 & 311.3 & 24.08 & 190.2 \\
\hline Soyuz & 39.92 & 311.4 & 23.78 & 185.5 \\
\hline \multicolumn{5}{|c|}{ Oil flax } \\
\hline Severny & 46.13 & 1347.0 & 18.40 & 537.3 \\
\hline LM-98 & 43.05 & 1050.4 & 21.38 & 521.7 \\
\hline Itil & 42.01 & 957.8 & 23.99 & 547.0 \\
\hline VNIIMK-620 & 43.23 & 894.9 & 21.05 & 435.7 \\
\hline Lirina & 45.21 & 1116.7 & 20.15 & 497.7 \\
\hline
\end{tabular}

Among oil flax varieties listed in the State Register, only VNIIMK 630, Istok, LM 98, Sanlin and the promising variety Itil are characterized by yellow coloring of the seed. These varieties show low content of linolenic acid in the flaxseed oil, which makes it oxidation-resistant and suitable for use in food along with traditional vegetable oil. Thus, the content of linolenic and linoleic acids in the oil of LM98 variety is $4 \%$ and $68.9 \%$, respectively. This ratio of acids is close to the optimum (1:10) recommended by the Joint FAO Committee (UN Agricultural and Food Organization) and the World Health Organization.

The pathogen that causes Fusarium wilt in flax is imperfect fungi from the genus Fusarium Link. Their species composition is variable, but flax is most often infected by F. oxysporum Schl. f. lini Snyd. et Hans (F, lini Bolley).

F. oxysporum $\mathrm{f}$. lini is an optional parasite. It has physiological races that differ in virulence. On organic residues in soil it can develop for more than 5 years, producing conidia and chlamydospores, which infect flax plants. Thus, the primary source of Fusarium infection can be contaminated soil, plant debris and seeds. During plant vegetation, the fungus spreads by growth of the mycelium throughout the soil and by conidia.

By the time of harvesting, the level of Fusarium induced infection in VNIIMK 620 and Raciol varieties was not high to cause a harmful effect, and in Severny variety, it was within the threashold of harmfulness. The highest yield was noted for Severny variety. The decreased yield for VNIIMK 620 and Raciol varieties was due to soil and air drought in mid-July 2019, when part of the ovaries and buds of flax plants died from high temperature and windburn (Table 5).

Table 5. Dynamics and incidence of Fusarium wilt in varieties of oil flax before harvesting, experimental plot, Kurgan State Agricultural Academy, 2019 


\begin{tabular}{|l|c|c|c|}
\hline \multicolumn{1}{|c|}{ Variety } & Dynamics (\%) & $\mathrm{K}_{\mathrm{a}}$ & Incidence (\%) \\
\hline $\begin{array}{l}\text { Severny } \\
\text { (standard) }\end{array}$ & 17.3 & 2.54 & 44.0 \\
\hline Uralsky & 36.6 & 1.96 & 72.0 \\
\hline Uralsky Zhelty & 55.3 & 1.44 & 90.0 \\
\hline Itil & 29.1 & 1.97 & 50.0 \\
\hline Lirina & 38.0 & 2.20 & 60.0 \\
\hline Raciol & 9.3 & 3.00 & 28.0 \\
\hline VNIIMK 620 & 11.3 & 3.00 & 34.0 \\
\hline
\end{tabular}

The increased threashold of harmfulness of Fusarium wilt was noted for Itil (1.94-fold), Uralsky (2.44-fold), Lirina (2.53-fold) and for Uralsky Zhelty variety (3.4-fold). The seed yield did not decrease due to a high adaptability coefficient of the varieties. At the same time, phyto-examination of the harvested crop should be carried out to assess the quality of seed material and the need for treatment.

The incidence of Fusarium wilt in control groups of fiber flax plants in 2017 and in 2018 remained at the same level and exceeded the harmfulness threshold 2.25fold and 2.16-fold, respectively (Table 6).

At the same time, we noted relative resistance to Fusarium fungi in Tomsky 17, Tomsky 18, Tost, Tost 3, Tost 4, Pamyati Krepkova fiber flax varieties. In addition, these varieties showed a high adaptive index.

Integrated pest management in 2017 and in 2018 helped reduce the incidence of Fusarium wilt in most of the fiber flax varieties to maintain it within the threshold of harmfulness.

Table 6. Fusarium wilt in control groups of fiber flax varieties, Kurgan State Agricultural Academy

\begin{tabular}{|l|c|c|c|c|c|c|}
\hline \multirow{2}{*}{ Variety } & \multicolumn{2}{|c|}{ Dynamics, \% } & \multicolumn{2}{c|}{$\mathrm{K}_{\mathrm{a}}$} & \multicolumn{2}{c|}{ Incidence, $\%$} \\
\cline { 2 - 7 } & 2017 & 2018 & 2017 & 2018 & 2017 & 2018 \\
\hline $\begin{array}{l}\text { Tomsky 17 } \\
\text { (standard) }\end{array}$ & 29.3 & 35.0 & 1.98 & 1.57 & 58.0 & 68.0 \\
\hline Tomsky 18 & 40.7 & 30.2 & 1.92 & 1.74 & 78.0 & 66.0 \\
\hline Tost & 32.7 & 29.9 & 2.02 & 1.67 & 66.0 & 71.0 \\
\hline Tost 3 & 38.7 & 30.4 & 1.86 & 2.05 & 72.0 & 75.0 \\
\hline Tost 4 & 30.0 & 35.6 & 2.07 & 1.73 & 62.0 & 82.0 \\
\hline Tomich & 34.0 & 38.5 & 1.88 & 1.80 & 64.0 & 84.0 \\
\hline $\begin{array}{l}\text { Pamyati } \\
\text { Krepkova }\end{array}$ & 27.3 & 37.8 & 2.20 & 2.14 & 60.0 & 80.0 \\
\hline Soyuz & 22.7 & 28.4 & 1.62 & 2.02 & 80.0 & 58.0 \\
\hline Smolensky & 49.3 & 24.7 & 2.29 & 1.86 & 52.0 & 46.0 \\
\hline Tost 5 & - & 33.2 & - & 1.59 & - & 69.0 \\
\hline $\begin{array}{l}\text { Average by } \\
\text { varieties }\end{array}$ & 33.8 & 32.4 & 1.98 & 1.85 & 65.8 & 69.9 \\
\hline LSD 0.95 & 3.1 & 1.9 & & & 5.2 & 4.3 \\
\hline
\end{tabular}

Protection of fiber flax implied pre-sowing treatment of seeds with Tebu $60(0.51 / \mathrm{t})+$ Biocomposite Correct (2 $1 / t)$. In the herringbone phase, the plants were treated with Biocomposite Correct (2 1/ha) + Biostim Maslichny (1 $1 / \mathrm{ha})$. In the budding phase, the plants were treated with Intermag Profi Oleistye microfertilizer (2 1/ha). In the control group, the seeds were not treated with protective agents.

During the growing season, experimental plants were treated with herbicides Lornet and BP (0.3 1/ha), and
Zinger and SP $(0.008 \mathrm{~kg} / \mathrm{ha})$ against dicotyledons and with Hiler and MKE (1 l/ha) against monocotyledonous weeds. Treatment was performed across the plots during the phase of 2nd-4th leaf in weeds and the phase of herringbone in flax plants. The flowrate of the working fluid was 200 1/ha.

The effectiveness of integrated pest management in 2017 contributed to a decrease in the incidence of Fusarium wilt in Tost 4 (1.3-fold), Tomsky (1.4-fold), Tost (1.6-fold), Pamyati Krepkova (1.7-fold), Tost 3 and Tomich (1.9-fold) and Tomsky 17 (2.1-fold) varieties (Table 7).

In 2018, biological effectiveness of pest management to reduce the incidence of Fusarium wilt in flax varieties was also high. The incidence of Fusarium wilt was observed to decrease in Tomsky 18 (1.99-fold), Tost (2.2-fold), Tost 5 (2.3-fold), Tomsky 17, Tost 3, Tomich (2.5-fold), Pamyati Krepkova (2.6-fold), and Tost 4 (2.8fold) varieties.

Table 7. Fusarium wilt of fiber flax varieties under integrated pest management, Kurgan State Agricultural Academy

\begin{tabular}{|l|c|c|c|c|c|c|}
\hline \multirow{2}{*}{ Variety } & \multicolumn{2}{|c|}{$\begin{array}{c}\text { Dynamics, } \\
\%\end{array}$} & \multicolumn{2}{c|}{$\mathrm{K}_{\mathrm{a}}$} & \multicolumn{2}{c|}{$\begin{array}{c}\text { Incidence, } \\
\%\end{array}$} \\
\cline { 2 - 7 } & 2017 & 2018 & 2017 & 2018 & 2017 & 2018 \\
\hline $\begin{array}{l}\text { Tomsky 17 } \\
\text { (standard) }\end{array}$ & 14.0 & 14.0 & 2.68 & 1.96 & 34.0 & 44.0 \\
\hline Tomsky 18 & 28.7 & 15.2 & 1.95 & 2.14 & 56.0 & 36.0 \\
\hline Tost & 20.7 & 13.5 & 2.13 & 2.07 & 44.0 & 51.0 \\
\hline Tost 3 & 20.0 & 12.0 & 2.30 & 2.40 & 46.0 & 52.0 \\
\hline Tost 4 & 22.7 & 12.9 & 2.29 & 1.93 & 52.0 & 43.0 \\
\hline Tomich & 18.0 & 15.6 & 2.67 & 1.98 & 48.0 & 39.0 \\
\hline $\begin{array}{l}\text { Pamyati } \\
\text { Krepkova }\end{array}$ & 16.0 & 14.8 & 2.50 & 2.42 & 40.0 & 35.0 \\
\hline Soyuz & 12.5 & 17.9 & 1.82 & 2.14 & 50.0 & 38.0 \\
\hline Smolensky & 26.9 & 16.7 & 2.30 & 1.92 & 31.0 & 36.0 \\
\hline Tost 5 & - & 14.2 & - & 2.00 & - & 38.0 \\
\hline $\begin{array}{l}\text { Average by } \\
\text { varieties }\end{array}$ & 19.9 & 14.7 & 2.29 & 2.10 & 44.6 & 41.2 \\
\hline LSD 0.95 & 2.4 & 1.1 & & & 4.4 & 3.2 \\
\hline
\end{tabular}

Integrated pest management significantly decreased the incidence of Fusarium wilt in fiber flax plants and increased their adaptive index.

Integrated pest management of flax varieties performed using phytosanitary cultivation technology provided a 1.19-fold increase in seed yield in 2017 and 1.2-fold increase in 2018 (Table 8).

Table 8. Seed yield of flax varieties under integrated pest management, Kurgan State Agricultural Academy

\begin{tabular}{|l|c|c|c|}
\hline \multirow{2}{*}{\multicolumn{1}{|c|}{ Variety }} & \multicolumn{3}{c|}{ Yield, t/ha } \\
\cline { 2 - 4 } & 2017 & 2018 & average \\
\hline Tomsky 17 (standard) & 1.06 & 1.07 & 1.06 \\
\hline Tomsky 18 & 1.02 & 1.18 & 1.10 \\
\hline Tost & 0.88 & 1.09 & 0.98 \\
\hline Tost 3 & 1.12 & 1.19 & 1.16 \\
\hline Tost 4 & 1.15 & 1.08 & 1.12 \\
\hline Tomich & 0.90 & 0.86 & 0.88 \\
\hline Pamyati Krepkova & 0.96 & 0.94 & 0.95 \\
\hline
\end{tabular}




\begin{tabular}{|l|c|c|c|}
\hline Soyuz & 0.92 & 0.90 & 0.91 \\
\hline Smolensky & 0.99 & 0.88 & 0.94 \\
\hline Tost 5 & - & 1.13 & $1.13^{*}$ \\
\hline Average by varieties & 1.00 & 1.02 & \\
\hline LSD $_{0.95}$ & 0.10 & 0.05 & \\
\hline
\end{tabular}

* data collected over 1 year of study

The highest seed yields over two years were obtained for Tomsky 17 (1.06 c/ha), Tomsky 18 (1.10 c/ha), Tost 3 (1.16 c/ha) and Tost 4 (1.12 c/ha) varieties. In 2018, the new variety Tost 5 showed a high seed yield.

Integrated pest management of fiber flax increased straw yield in 2018 for Tomsky 17 (by $20.8 \%$ ), Tomsky $18(22.8 \%)$, Tost $(28.1 \%)$, Tost $3(24.4 \%)$, Tost 4 $(20.5 \%)$ and Tost $5(10.5 \%)$ varieties (Table 9).

The average economic efficiency of pest management by varieties was $117 \%$ in 2017 and $124 \%$ in 2018.

Table 9. Straw yield of fiber flax varieties under integrated pest management, Kurgan State Agricultural Academy

\begin{tabular}{|l|c|c|c|}
\hline \multirow{2}{*}{\multicolumn{1}{c|}{ Variety }} & \multicolumn{3}{c|}{ Yield, t/ha } \\
\cline { 2 - 4 } & 2017 & 2018 & average \\
\hline Tomsky 17 & 3.42 & 2.38 & 2.90 \\
\hline Tomsky 18 & 3.05 & 2.80 & 2.93 \\
\hline Tost & 2.97 & 2.46 & 2.72 \\
\hline Tost 3 & 3.56 & 2.55 & 3.06 \\
\hline Tost 4 & 3.37 & 2.35 & 2.86 \\
\hline Tomich & 2.82 & 2.14 & 2.48 \\
\hline Pamyati Krepkova & 2.97 & 2.22 & 2.60 \\
\hline Soyuz & 3.05 & 3.02 & 3.04 \\
\hline Smolensky & 3.20 & 3.10 & 3.15 \\
\hline Tost 5 & - & 2.31 & $2.31 *$ \\
\hline Average by varieties & 3.16 & 2.53 & \\
\hline LSD0.95 & 0.27 & 0.21 & \\
\hline
\end{tabular}

* data collected over 1 year of study

The yield of fiber flax straw under integrated pest management was 1.25 times higher in 2017 than that in 2018 , which may be due to the hydrothermal conditions of the growing season, which decreased the fiber flax yield during this period.

\section{Conclusion}

In Kurgan region, the area covered by flax plants increased from 2750 ha in 2012 to 65586 ha in 2019, oil flax occupies $95 \%$ of the area. At the same time, the yield remained sufficiently low - from 0.75 t/ha in 2016 to $1.36 \mathrm{t} / \mathrm{ha}$ in 2018 . New varieties of oil flax show a rather high seed yield (2.3-2.6 t/ha) with an oil content of up to $49.5-53.0 \%$ and a protein content of up to $33 \%$.

Severny variety, which occupies more than half of the areas in Kurgan region, exhibited a high yield potential as a standard variety (2.92 t/ha). In 2019, domestic varieties of oil flax Uralsky and Uralsky Zhelty breeded by the staff of Ural Scientific Research Institute of Agriculture showed high yields. Among foreign varieties, Lirina was of interest and exhibited a lower yield potential compared to the standard Severny variety. The yield of VNIIMK 620 and Raciol varieties reduced in response to adverse weather conditions in midsummer.

The results of the three-year study showed a high seed yield of the new varieties of fiber flax exhibited: Tost $3-0.98 \mathrm{t} / \mathrm{ha}$, Tost $4-0.86 \mathrm{t} / \mathrm{ha}$, Tost $5-0.82 \mathrm{t} / \mathrm{ha}$. Seed yield of traditionally cultivated varieties was as follows: Tomsk $17-0.87 \mathrm{t} / \mathrm{ha}$, Tomsk $18-0.89 \mathrm{t} / \mathrm{ha}$, Tost $-0.79 \mathrm{t} / \mathrm{ha}$. The varieties grown in the study area as a standard showed high fiber yields: Tomsky 17 $0.68 \mathrm{t} / \mathrm{ha}$, Tomsky $18-0.69 \mathrm{t} / \mathrm{ha}$.

\section{References}

1. A.P. Kolotov, O.V. Sinyakova, Realization of the genetic seed yield potential of oil flax in the Middle Urals, AIC of Russia, 72(1), 92-96 (2015)

2. E.V. Korepanova, V.N. Goreeva, M.P. Maslova, Comparative evaluation of flax varieties in the Middle Urals, Bull. of Ulyanovsk State Agricult. Acad., 4(20), 9-14 (2012)

3. E.V. Korepanova, I.Sh. Fatykhov, Ecological plasticity of flax varieties in the Middle Urals, Bull. of Samara State Agricult. Acad., 4, 27-30 (2012)

4. E.V. Korepanova, I.Sh. Fatykhov, Quality of stocks and elemental composition of seeds of fiber flax varieties in the Middle Urals, Agrochem. Bull.. 3, 57 (2012)

5. N.A. Kuptsevich, Optimization of flax cultivation technology in the conditions of the South TransUrals, Bull. of Kurgan State Agricult. Acad., 3, 3641 (2018)

6. N.A. Kuptsevich, I.N. Porsev, E.Yu. Toropova, Adaptive phytosanitary technology of flax cultivation in Trans-Ural region (Kurgan State University Publ. House, Kurgan, 2019) 240 p.

7. Flax cultivation in Siberia: current status and development prospects: Proc. of the All-Russ. Sci.pract. Conf. (Tara branch FSBEI HE Omsk SAU, 2013) $81 \mathrm{p}$.

8. B.A. Dospekhov, Methodology of experimental work (Kolos, Moscow, 1985) $335 \mathrm{p}$.

9. Guidelines for conducting field experiments with fiber flax (Torzhok, 1978) $73 \mathrm{p}$.

10. I.N. Porsev, E.Yu. Toropova, N.A. Kuptsevich, K.S. Salomatina, Yield of fiber flax and oil flax depending on the variety composition in the central zone of Kurgan region, Bull. of Kurgan State Agricult. Acad., 1, 34-37 (2016) 